\title{
Genomic imprinting of PPP1R9A encoding neurabin I in skeletal muscle and extra-embryonic tissues
}

\author{
K Nakabayashi, S Makino*, S Minagawa*t, A C Smith, J S Bamforth, P Stanier, M Preece, \\ L Parker-Katiraee, T Paton, M Oshimura, P Mill, Y Yoshikawał, C C Hui, D Monk, G E Moore, \\ S W Scherer
}

G enomic imprinting is a phenomenon whereby genes are differentially expressed according to their parental origin. ${ }^{12}$ Mutations which affect the epigenetic states of imprinted domains underlie a number of diseases, including developmental abnormalities, malignant tumours, and psychiatric diseases. ${ }^{3}$ To date, $>50$ imprinted genes have been identified in human and mouse (www.otago.ac.nz/ IGC). For some genes, imprinting has been shown to be tissue specific ${ }^{4-9}$ and/or developmentally regulated. ${ }^{10}{ }^{11}$ For others, polymorphic imprinting (the term for the imprinting of a gene that is variable between individuals) has also been observed. ${ }^{12}{ }^{13}$ These variations in gene expression are considered to be a source of phenotypic heterogeneity in human disease with parent-of-origin effects. ${ }^{4}$

Three imprinted loci have been identified on human chromosome $7 .{ }^{14}$ One of the loci is located on 7q21.3 and two genes, SGCE and PEG10, are known to be imprinted (fig lA). Initially the mouse Sgce gene (encoding sarcoglycanepsilon) was identified as a maternally imprinted (paternally expressed) gene in a subtractive screening experiment using cDNA libraries derived from parthenogenetic and wild-type fibroblast lines. ${ }^{15}$ The human SGCE gene has also been confirmed to be imprinted. ${ }^{16-18}$ PEG10 (paternally expressed gene 10), which is immediately telomeric to $S G C E$, was also shown to be imprinted in embryonic villi. ${ }^{19}$ Moreover, the mouse Asb4 gene (ankyrin repeat and SOCS box-containing protein 4), which is $800 \mathrm{~kb}$ telomeric to Sgce, was found to be maternally expressed by cDNA micro-array based highthroughput screening for genes differentially expressed between mouse parthenogenetic and androgenetic embryos. ${ }^{6}$ The imprinting status of the human ASB4 and other genes adjacent to $S G C E / P E G 10$ has not yet been determined, but systematic imprinting analyses of mouse genes indicate that the $1 \mathrm{Mb}$ interval encompassing Sgce/Peglo is part of a large imprinted locus; Peglo was confirmed to be paternally expressed, and neurabin (Ppplr9a), Pon2, and Pon3 were found to be preferentially maternally expressed. ${ }^{20}$ The mouse calcitonin receptor gene (Calcr), which is located $1.2 \mathrm{Mb}$ centromeric to the Sgce/Peglo locus, was recently shown to be imprinted in a brain specific manner. ${ }^{9}$ Moreover, $D L X 5$, a gene located $2.4 \mathrm{Mb}$ telomeric to the SGCE/PEG10 locus, is imprinted in human lymphoblasts and brain tissue. ${ }^{21}$ These findings raise the possibility that the cluster of imprinted genes identified in mouse (Sgce to Asb4) could extend further in both centromeric and telomeric directions.

The human PPPIR9A gene encoding neurabin I is adjacent to SGCE, PEG10, and ASB4 (fig 1A). Neurabin I (neural tissue specific F-actin-binding protein I) was originally purified from rat brain and has been characterised as a key candidate molecule in synaptic formation and function. ${ }^{22}$ It has also been shown that neurabin I is highly concentrated in the synapse of developed neurons and is involved in neurite formation. The deduced 1098 amino acid sequence for rat

\section{Key points}

- Deregulation of imprinted genes has been observed in various human diseases. The human PPPIR9A gene, which encodes neurabin I, is located in a cluster of imprinted genes on human chromosome 7q21. The protein has been shown to be a regulatory subunit of protein phosphatase I, and controls actin cytoskeleton reorganisation.

- The expression patterns of human and mouse PPP1R9A gene were analysed by Northern blot and RNA in situ hybridisation. Allelic expression patterns were determined by DNA sequencing and a single nucleotide primer extension method (SNaPshot assay). PPP1R9A was found to be transcribed in both neuronal and multiple embryonic tissues. In allelic expression analyses in human and mouse, the gene was found to be preferentially transcribed from the maternally inherited chromosome mainly in embryonic skeletal muscle tissues, but was biallelically expressed in other embryonic tissues. Preferential or exclusive maternal expression was also observed in extra-embryonic tissues.

- Our findings suggest that PPPIR9A is not neuronal specific as shown previously, but rather important for early development of multiple tissues, some being influenced by the imprinting status. Dosage control of neurabin I through imprinting mechanisms may be necessary for proper skeletal muscle differentiation, which requires reorganisation of the actin cytoskeleton.

neurabin I contains an F-actin-binding domain, a PDZ domain, and coiled-coil domains. ${ }^{22}$ As the name indicates, the expression of the gene and protein was shown to be brain specific in adult rat tissues. ${ }^{22}{ }^{23}$ The gene symbol is based on "protein phosphatase $\underline{1}$, regulatory (inhibitor) subunit $\underline{9 \mathrm{~A}^{\prime}}$ because neurabin I has been shown to bind protein phosphatase I (PPl) and inhibit its activity. ${ }^{24}$ The PPl/ neurabin I complex has been demonstrated to regulate actin cytoskeleton dynamics. ${ }^{25}$ Furthermore, molecules implicated in the control of neuronal morphology, such as p70S6 $\mathrm{K}^{23}$ and kalirin-7 (a GTP-exchange factor), ${ }^{26}$ have been identified to bind the PDZ domain of neurabin I. Lastly, the C-terminus of neurabin I binds the trans-Golgi protein TGN38, suggesting it is a multi-functional molecule that regulates membrane and cytoskeletal functions. ${ }^{27}$

Abbreviations: dpc, day post coitum; SNP, single nucleotide polymorphism 
The mouse Ppplr9a was shown recently to be preferentially maternally expressed in extra-embryonic tissue, but biallelically in neonatal tissue. ${ }^{20}$ Independently, we were conducting imprinting analyses for $P P P 19 A$ since imprinted genes are often clustered, making PPPIR9A an obvious positional candidate to study. Moreover, since some imprinted genes are thought to be involved in mental dysfunction ${ }^{28}$ and maternal nurturing behaviour, ${ }^{29}$ we aimed to determine if PPPIR9A could be related to neurobehavioural disorders with parent-of-origin effects associated with chromosome 7. Intriguingly, PPPIR9A was found to be imprinted (maternally expressed) mainly in skeletal muscle tissues, but not in brain. Ppplr9a was also imprinted in extra-embryonic tissues in mouse. Taken together, our data indicate that neurabin I is not neuronal specific as previously described and its differential expression could play an important role in multiple tissues.

\section{METHODS}

\section{mRNA sequence for mouse Ppp 1r9a}

The exon-intron structure of the mouse Ppplr9a gene was estimated by the alignment of human mRNA sequences (AK096514 and AB033048) with mouse genomic DNA by BLAT (http://genome.ucsc.edu). PCR primers mNeu-F (5'ATGAGCATTGGCTTTTCACC- $3^{\prime}$ ) on exon 2 and mNeu-R 5'-GGCGGGACTTCTCTCAAACT-3' on exon 16 were used in RT-PCR to amplify cDNA fragments containing the entire open reading frame for the mouse Ppplr9a gene. Randomprimed cDNA from total RNA of 15.5 day post coitum (dpc) brain was used as template DNA with PfuUltra High-Fidelity DNA Polymerase (Stratagene). The cycling conditions were: initial denaturation at $94^{\circ} \mathrm{C}$ for $3 \mathrm{~min}$, followed by 35 cycles of denaturation at $94^{\circ} \mathrm{C}$ for $30 \mathrm{~s}$, annealing at $55^{\circ} \mathrm{C}$ for $30 \mathrm{~s}$, and extension at $72^{\circ} \mathrm{C}$ for $4 \mathrm{~min}$. The amplified products (3.4 $\mathrm{kb}$ in size) were subcloned into the pCR-Script vector (Stratagene) and sequenced.

\section{Northern blot analysis}

A human MTN blot (Clontech, 7760-1) containing poly A RNA (2 $\mu \mathrm{g}$ per lane) from human adult tissues was hybridised with ${ }^{32} \mathrm{P}[\alpha] \mathrm{dCTP}$-labeled probe ( $187 \mathrm{bp}$ fragment corresponding to nt 3063-3249 of GenBank acc. number AB033048). The hybridisation and washing conditions were described previously. ${ }^{30}$

\section{RNA in situ hybridisation}

A $447 \mathrm{bp}$ fragment corresponding to nt 3857-4303 of GenBank acc. number AY308065 was subcloned into
pCR-Script vector (Stratagene) and used as template DNA for sense/antisense riboprobes. Probes were hybridised with paraffin-embedded sagittal sections of $15.5 \mathrm{dpc}$ embryo (from the CDl strain). The conditions used for hybridisation, washing, and signal detection were described previously. ${ }^{31}$

\section{Allelic expression analysis on human fetal samples}

A 201 bp DNA fragment was amplified from fetal genomic DNA using primers exl61F/1R (5'-CACTGGCAAACAC AACACAG-3' and 5'-GTCCTTTGGAAAGTGGATAACC-3'), and was sequenced to determine the genotype for SNP rs854541 on exon 16. Primers AB033048-1813F/3249R (5'GCCTGGATATGATAGATGACGA-3' and 5'-CCACCTGGG AAATCTTGAGT-3') were used to amplify a 1437 bp fragment (for isoform I) from fetal cDNAs. The cycling conditions were: initial denaturation at $94^{\circ} \mathrm{C}$ for $3 \mathrm{~min}$, followed by 38 40 cycles of denaturation at $94^{\circ} \mathrm{C}$ for $30 \mathrm{~s}$, annealing at $58^{\circ} \mathrm{C}$ for $30 \mathrm{~s}$, and extension at $72^{\circ} \mathrm{C}$ for $90 \mathrm{~s}$. AB033048-3249R was used as a sequencing primer.

A 499 bp DNA fragment was amplified from fetal genomic DNA using primers $12 \mathrm{~b}-1 \mathrm{~F} / 1 \mathrm{R}$ (5'-CTCAGTGGCATAA

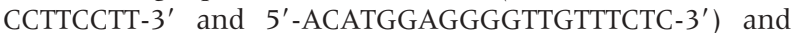
sequenced to determine the genotype for SNP rs854524 on exon 12b. Primers AK000075-174F/632R (5'-CCCTTCTCGTCT GACCACAT-3' and 5'-TTTCCGGCTGTCATTAAACC-3') were used to amplify cDNA products (459 bp) for isoform II. The cycling conditions were: initial denaturation at $94^{\circ} \mathrm{C}$ for $3 \mathrm{~min}$, followed by $35-38$ cycles of denaturation at $94^{\circ} \mathrm{C}$ for $30 \mathrm{~s}$, annealing at $58{ }^{\circ} \mathrm{C}$ for $30 \mathrm{~s}$, and extension at $72^{\circ} \mathrm{C}$ for $45 \mathrm{~s}$. AK000075-524R was used as a sequencing primer.

The PCR products were purified using microCLEAN (Microsone) and were sequenced directly using Big Dye terminator kit and resolved on a 310 Genetic Analyzer (Applied Biosystems).

To determine the allelic expression pattern of the PPPIR9A by DNA sequencing, the region containing the peaks for the SNP sites was enlarged on imaging software, and the heights of the two alleles (A and B) were measured. When the peak ratio $(\mathrm{A} / \mathrm{B})$ in a cDNA sample was between 50 and $200 \%$ compared with that of heterozygous genomic DNA control, PPPIR9A was regarded as being biallelically expressed.

\section{Allelic expression analysis on mouse embryonic samples}

Total RNA was extracted from embryonic tissues (12.5 dpc, $15.5 \mathrm{dpc}$, and postnatal (P0)) from reciprocal Fl crosses between C57BL/6J and CAST/Ei. CDNA was synthesised using random primers. Primers 441F (5'-TCACGGAGACTCGAAA

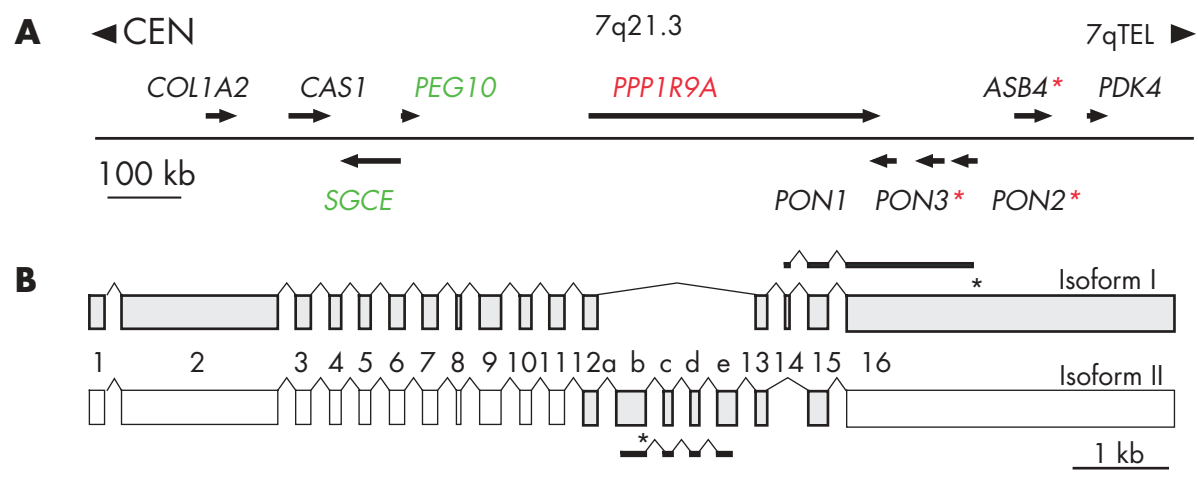

Figure 1 (A) A 1.2 Mb interval containing three imprinted genes and PPP1R9A on human chromosome 7q21.3. Genes shown to be imprinted in human are highlighted in green (paternally expressed) or red (maternally expressed). Red asterisks indicate the genes whose mouse orthologue is shown to be preferentially maternally expressed, but whose patterns in human have yet to be determined. (B) Exon-intron structure of the human PPPIR9A gene and SNPs (single nucleotide polymorphisms) used for allelic expression analysis. Two alternative spliced isoforms I and II are shown. Only the size of exons are drawn to scale (the gene encompasses $385 \mathrm{~kb}$ as indicated in panel A). SNPs used for allelic expression experiments are marked by asterisks. The positions of DNA fragments amplified by RT-PCR and sequenced for allelic expression patterns are shown by black bars. 
GATGT-3') and 1471R (5'-GTCGTCATTTCTCCGGTCAT-3') were used for RT-PCR to amplify a $1031 \mathrm{bp}$ fragment containing SNPs in exon 2 (nt 536 and 616 of GenBank acc. number AY308065), followed by direct sequencing by primer 759R ( 5'-TTGGTGACGGTAACAGATGG-3').

\section{Quantitative allelic expression analysis (SNaPshot assay)}

PCR products were purified by QIAquick Gel Extraction Kit (Qiagen). Purified PCR product (0.01-0.40 pmol) was used for SNaPshot primer extension reaction. A $0.2 \mu \mathrm{M}$ of primer and $2 \mu \mathrm{l}$ SNaPshot Ready Reaction Mix containing fluorescence-labelled ddNTPs, Amplitaq DNA polymerase, and reaction buffer (Applied Biosystems) were added to a total volume of $10 \mu \mathrm{l}$. The extension primers used were 5'-TGTTCAATTTCTTGGGTTAGGT-3' for rs854541 (PPPIR9A isoform I), 5'-AAACCACCAACAAGAAAATATTAC-3' for rs854524 (PPPIR9A isoform II), and 5'-GAGCCCCC GGACGGAAGC-3' for nt 616 of AY308065 (mouse Ppplr9a). The cycling conditions for the reaction were 25 cycles at $95^{\circ} \mathrm{C}$ for $10 \mathrm{~s}, 58^{\circ} \mathrm{C}$ for $5 \mathrm{~s}$, and $60^{\circ} \mathrm{C}$ for $30 \mathrm{~s}$. One unit of shrimp alkali phosphatase was added, and the mixture was incubated at $37^{\circ} \mathrm{C}$ for $1 \mathrm{~h}$, followed by $75^{\circ} \mathrm{C}$ for $15 \mathrm{~min}$. The reactions were resolved on an ABI 3100 Genetic Analyzer, and signal intensities for two alleles at an SNP site were measured using GeneScan Analysis Software Version 3.5. The percentage ratio of the two alleles at SNP sites for cDNA samples was corrected using the mean of the ratios obtained from analyses of three heterozygous genomic DNA samples as described previously. ${ }^{32}$

\section{DNA methylation analysis}

Genomic DNA was isolated from normal, mUPD7, and pUPD7 lymphoblastoid cells. The mUPD7 and pUPD7 patients had undergone microsatellite repeat analysis to confirm uniparental disomy for the entire length of chromosome $7 .^{33}$ Tissue specific methylation was analysed in fetal liver, fetal muscle, and placenta. A $15 \mu \mathrm{g}$ sample of genomic DNA was pre-digested with $X b a \mathrm{I}$, then with the methylation-sensitive HpaII or Hin6I, or the HpaII methylation-insensitive isoschizomer MspI, before electrophoresis and Southern blot transfer to Hybond $\mathrm{N}+$ membrane. The filters were probed with a $1.3 \mathrm{~kb}$ PCR product (nt 59398-60715 of AC073886). Filters were pre-hybridised $\left(0.2 \mathrm{M} \mathrm{NaPO}_{4} \mathrm{pH} 7.2\right.$, 1 mM EDTA, $1 \%$ BSA, $7 \%$ SDS, $15 \%$ deionised formamide) for a minimum of $3 \mathrm{~h} / 65^{\circ} \mathrm{C}$, and hybridised with a radio-labelled probe overnight. Filters were washed three times $(40 \mathrm{mM} \mathrm{NaPO}$, $1 \mathrm{mM}$ EDTA, $1 \%$ SDS) for $7 \mathrm{~min} / 65^{\circ} \mathrm{C}$. Blots were exposed to $x$ ray film with intensifying screens at $-70^{\circ} \mathrm{C}$ for 1 week.

\section{RESULTS}

\section{Gene structure and expression pattern of the human} and mouse PPPIR9A gene

GenBank acc. number U72994 represents the mRNA sequence containing the entire open reading frame of the rat neurabin I protein (1095 amino acids). ${ }^{22}$ The human mRNAs, AK096514 and AB033048, were found to contain the entire open reading frame for the neurabin I protein (1098 amino acids), which showed $90 \%$ sequence homology with the rat protein sequence. Alignment of the human mRNA sequences with genomic DNA sequence revealed that human PPPIR9A is composed of 16 exons encompassing $385 \mathrm{~kb}$ of DNA. We designated this exon-intron structure to be isoform I (fig 1B). A partial mRNA sequence (AK000075) was found to contain additional exons (12b-12e) between exon 12a and 13, but it lacked exon 14 (fig 1B). We have, therefore, designated this as isoform II and could confirm by RT-PCR that it shared the exon-intron structure with isoform I for the rest of exons (data not shown). ESTs AW205092 and
BG183318 were found to contain an alternative form of exon 12e (named $12 \mathrm{e}^{\prime}$ ), which is $115 \mathrm{bp}$ longer because of an alternative splicing donor site (this was designated PPPIR9A isoform III). We determined the mRNA sequence for the mouse PppIr9a gene (GenBank acc. number AY308065) by sequencing RT-PCR products containing the entire open reading frame (exons 2-16, see Methods).

Previously, neurabin I was shown to be expressed only in the brain among rat adult tissues. ${ }^{22}{ }^{23}$ However, our Northern blot analysis detected a $9.5 \mathrm{~kb}$ band in the brain and skeletal muscle among eight human adult tissues examined (fig 2A). The mouse gene has been shown to be expressed in adult skeletal muscle. ${ }^{34}$ Therefore, the expression of neurabin I in skeletal muscle may be age-dependent in the adult stage of these species. Alternatively, developmental regulation for the gene in skeletal muscle tissues may be different among species.

The expression of Ppplr9a in embryonic development was also examined by RNA in situ hybridisation. At 15.5 days post coitum (dpc), Ppp Ir9a is highly expressed in the brain and the skeletal muscle (fig 2B). In the brain, Ppplr9a is strongly expressed in the neopallial cortex (future cerebral cortex) and diencephalon (thalamus). The gene is also expressed in the skeletal muscle, in the developing tongue, in the cervical region, and around the primordium of the costal and scapula cartilages (data not shown).

\section{Allelic expression analysis in human fetal tissues}

Alternatively spliced isoforms I and II of human PPPIR9A were examined for their imprinting status. Single nucleotide polymorphisms (SNPs) rs854541 in exon 16 and rs854524 in exon $12 \mathrm{~b}$ were used for allelic expression analysis for isoforms I and II, respectively (fig $1 \mathrm{~B}$ ). Isoform III was excluded from the analysis because of its low expression level (data not shown). Eight and six fetuses were found to be heterozygous for the SNPs in isoforms I and II, respectively (table 1 ). The allelic expression pattern of PPPIR9A isoforms in 10 types of tissues from those fetuses was initially assessed by direct sequencing of RT-PCR products, and preferential or monoallelic expression was observed in some tissues (fig 3A). The observed biased allelic expression was confirmed to be reproducible in at least two independent experiments. To quantitate the allelic expression ratio, the same fetal cDNA samples (if available) were subjected to SNaPshot assay (Applied Biosystems), which is a fluorescence-based primer extension method and has been applied for quantitative allele frequency measurement for SNPs. ${ }^{32} 3536$ Examples of SNaPshot outputs are shown in fig 3B. Table 1 summarises the percentage ratio of the two alleles determined by SNaPshot assay or allelic expression pattern determined by DNA sequencing. Monoallelic expression in the tongue of fetus IC-77 for both isoforms, and preferential expression in the eye of fetus IC-77 for isoform I were detected by DNA sequencing (fig 3A). The allelic expression pattern for the remaining tissues from IC-77, the tissues from IC-46 and IC-58, and the brain from IC-56 were determined to be biallelic (see Methods for the criterion). Although determination of the allelic expression pattern by DNA sequencing is not quantitative, our results clearly showed that PPPIR9A is monoallelically expressed in tongue.

Mono-allelic or preferential expression was detected mainly in skeletal muscle tissues (limb and tongue) and also in eye and placenta (but with a lower frequency) (table 1). The maternal allele was exclusively or preferentially expressed in three informative cases (fetus IC-37, 56, and 77).

\section{DNA methylation analysis in human lymphoblastoid cell lines and fetal tissues}

A CpG island overlapping with exon 1 of PPPIR9A was found using the default setting ( $\mathrm{GC}>50 \%$, length $>200$, Obs CpG/ 


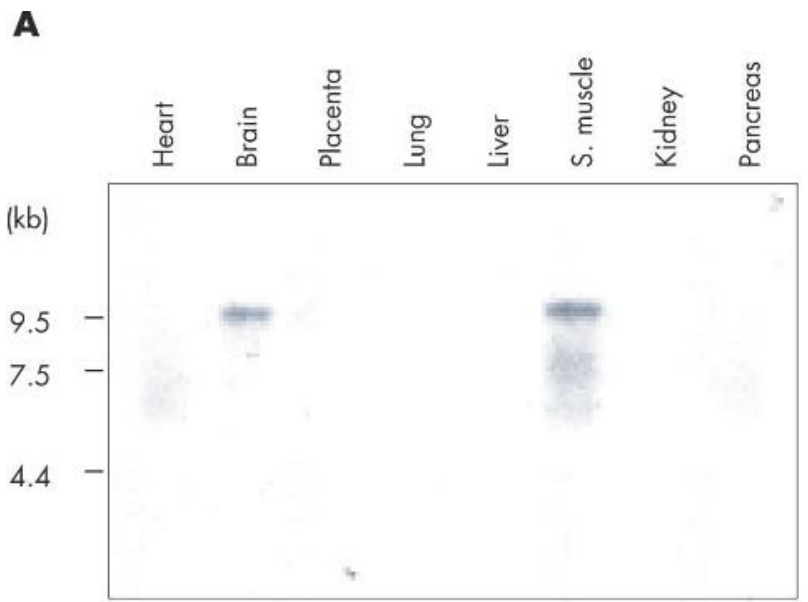

B

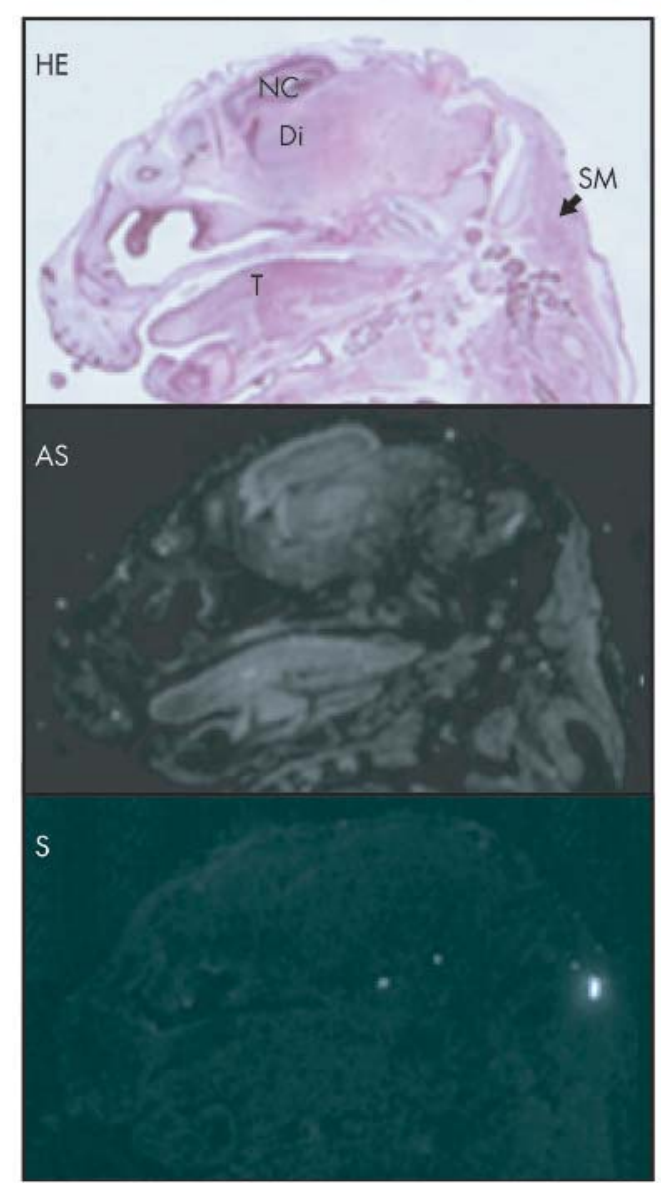

Figure 2 (A) Northern blot analysis of the human PPPIR9A gene on human adult tissues. Northern blot data demonstrate expression in brain and skeletal muscle. (B) RNA in situ hybridisation for the mouse Ppp 1 r9a gene on the head of $15.5 \mathrm{dpc}$ mouse embryo. The top panel shows a haematoxylin-eosin (HE) stained section. Di, diencephalons; NC, neopallial cortex; SM, skeletal muscle at the cervical region; $T$, tongue. The middle and bottom panels show the patterns of hybridisation signals detected by antisense (AS) and control sense (S) probes, respectively.

Exp $\mathrm{CpG}>0.6$ ) of the $\mathrm{CpG}$ island prediction algorithm in the UCSC Genome Browser (http://genome.cse.ucsc.edu). The CpG island is $627 \mathrm{bp}$ in length (83 CpG dinucleotides; $\% C G=73.6$ ) and corresponds to nt 59785-6041l of GenBank acc. number AC073886. Ten HpaII and 12 Hin6I methylation-sensitive restriction sites were found in the CpG island. The methylation status of these sites was examined in lymphoblastoid cell lines derived from individuals with bi-parental inheritance or uniparental disomy of chromosome 7 (UPD7) and fetal tissues (placenta, liver, and muscle) by Southern blot hybridisation. A $1.3 \mathrm{~kb}$ probe encompassing the entire CpG island was hybridised with blots containing genomic DNA digested with XbaI only, XbaI and Hin6I, XbaI and HpaII, and XbaI and MspI (the methylation-insensitive isoschizomer of HpaII) (fig 4). The same band pattern was detected on genomic DNA derived from paternal and maternal UPD7 lymphoblastoid cell lines, suggesting that the CpG island is not differentially methylated between two parental alleles in lymphoblastoid cell lines. No evidence for differential or tissue specific methylation was observed in the three fetal tissues tested, including muscle, where imprinted expression was detected.

\section{Imprinting analysis in mouse embryonic tissues from reciprocal $\mathrm{F} 1$ hybrids}

The imprinting pattern of the mouse orthologue (Ppplr9a) was examined by DNA sequencing and SNaPshot assays in embryonic and extra-embryonic tissues of interspecific reciprocal crosses between C57BL/6J (B6) and CAST/Ei. Fl hybrids between female B6 and male CAST, and female CAST and male $\mathrm{B} 6$ are designated as $\mathrm{BxC}$ and $\mathrm{CxB}$, respectively. SNPs between B6 and CAST were identified in exon 2 (nt 536 and 616 of acc. number AY308065) and exon 16 (nt 3980, 4124, and 4381 of acc. number AB091828). Consistent with the exon-intron structure of the human gene, RT-PCR using primers spanning exon 12a to exon 16 for the mouse Ppp Ir9a gene detected spliced isoforms in some of the tissues tested (data not shown). The allelic expression pattern of the mouse gene was primarily assessed by sequencing a 1031 bp cDNA fragment (nt 441-1471 of GenBank acc. number AY308065) that contains the two SNPs in exon 2 and spans exons 2-4. The RT-PCR products for the region are presumably amplified from multiple alternatively spliced isoforms between exon $12 \mathrm{a}$ and exon 16. However, since no isoform specificity was observed in the imprinting pattern of the human gene, allelic expression analysis for each spliced isoform was not performed for the mouse gene.

Consistent with the allelic expression pattern observed for the human PPPIR9A, preferential maternal expression was detected only in limb and tongue, most clearly in the postnatal stage (P0), among the nine embryonic tissues examined (table 2). The allelic expression pattern of Ppplr9a in heart (12.5 and $15.5 \mathrm{dpc}$ ), intestine (15.5 dpc), and skin (15.5 dpc) from $\mathrm{BxC}$ and $\mathrm{CxB}$ hybrids was assessed by DNA sequencing only and found to be biallelic (data not shown). Brain and tongue from reciprocal Fl hybrid embryos between B6 and $\mathrm{JF}$ l/Ms (designated as BxJ and $\mathrm{JxB}$ ) were also analysed using an SNP at nt 616 of acc. number AY308065, and preferential maternal expression of Ppplr9a was observed in tongue, but not in brain. Yolk sac was found to show the most striking maternal specific expression in the mouse tissues analysed; exclusive maternal expression was detected at $15.5 \mathrm{dpc}$ in $\mathrm{BxC}$ hybrids (fig 5 and table 1). Placenta also demonstrated preferential maternal expression, although we cannot exclude the possibility that the observed maternal preferential expression is due to contamination of maternal decidua.

The degree of maternal specific expression was developmental stage specific in skeletal muscle tissues and yolk sac, being markedly greater during the latter developmental stage. Imprinting was found to be more relaxed when the paternal allele was derived from B6 than from CAST or JF1. This tendency was consistent for all developmental stages in all four tissues in which preferential maternal expression was detected (fig 5 and table 2). For all tissues where monoallelic or preferential expression was observed, at least two independent embryos were subjected to allelic expression analyses. The extent of mono-allelic/preferential expression 
A

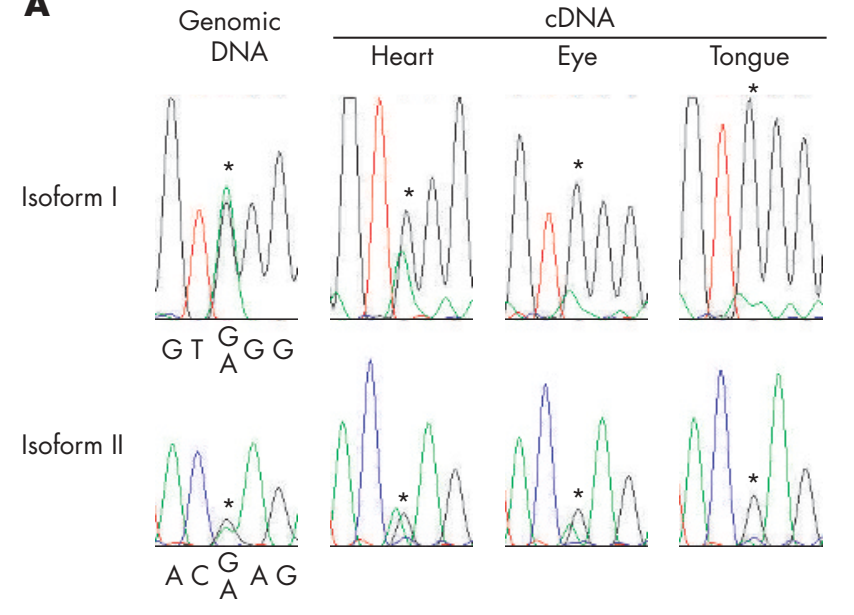

B
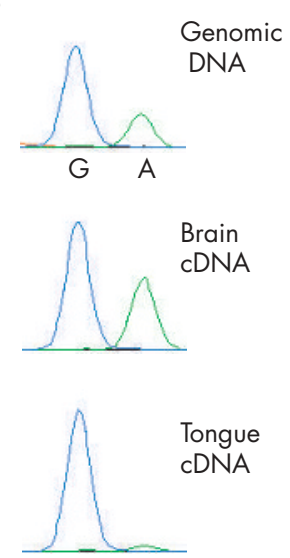

Figure 3 Allelic expression analysis for the human PPPIR9A isoforms. (A) Electropherograms for the sequencing of genomic DNA and cDNAs (heart, eye, and tongue) for fetus IC-77 are shown. Upper and lower panels are for isoforms I and II, respectively. Asterisks show the positions of SNPs (rs854541 for isoform I and rs854524 for isoform II). IC-77 was heterozygous for both SNPs. Biallelic or biased allelic expression was observed in the tissues examined. (B) Examples of quantitative SNaPshot data. The three panels are for SNP rs854541 (isoform I) on genomic DNA, brain CDNA, and tongue cDNA for fetus IC-62. The blue and green peaks represent $G$ and A alleles, respectively. Note the unequal heights for the two alleles on genomic DNA. Unequal allelic detection for heterozygous SNP sites has been frequently observed. ${ }^{36-38}$ This is considered to be due to background and other factors influencing peak heights (such as differential efficiencies of the incorporation of the ddNTPs and the unequal emission energies of the different fluorescent dyes). The allelic expression ratios for cDNA samples were corrected by the equation used elsewhere. ${ }^{36}$

was reproducibly similar between the same type/stage of tissues from different embryos.

\section{DISCUSSION}

Our finding that Ppplr9a is imprinted in placenta and yolk sac fits well with the idea that parent-of-origin specific gene expression is most often observed in extra-embryonic tissues ${ }^{8}$ and is consistent with the results of Ono et al..$^{20}$ However, the pattern of tissue specific imprinting observed in embryonic tissues is intriguing. This is the first report of skeletal muscle specific imprinting in embryonic tissues conserved between human and mouse. Biased allelic expression was also observed in some of the human fetal eye samples, but not in the eye samples from 15.5 dpc mouse embryos. Ppplr9a may be imprinted in a limited type of ocular cells at a certain developmental stage; allelic expression analyses specific to each cell type from eye would be required to assess such a possibility. It is also possible that PppIr9a is imprinted in

Table 1 Allelic expression analysis for the human PPPIR9A isoforms

\begin{tabular}{|c|c|c|c|c|c|c|c|c|c|c|c|c|c|}
\hline \multirow[b]{2}{*}{ Isoform } & \multirow[b]{2}{*}{ Fetus } & \multirow[b]{2}{*}{ G.W.* } & \multirow[b]{2}{*}{$\begin{array}{l}\text { Mother's } \\
\text { genotype }\end{array}$} & \multicolumn{9}{|c|}{ Embryonic tissues } & \multirow{2}{*}{$\begin{array}{l}\begin{array}{l}\text { Extra-embryonic } \\
\text { tissue }\end{array} \\
\text { Placenta }\end{array}$} \\
\hline & & & & Brain & Heart & Intestine & Liver & $\begin{array}{l}\text { Spinal } \\
\text { cord }\end{array}$ & Skin & Eye & Limb & Tongue & \\
\hline \multirow[t]{13}{*}{ I } & UA-D & - & - & G 50\% & - & - & - & - & - & - & G $18 \%$ & - & - \\
\hline & & & & A $50 \%$ & - & - & - & - & - & - & A $82 \%$ & - & - \\
\hline & IC-35 & 11 & $\mathrm{~N}$ & G $45 \%$ & - & - & - & - & - & G 32\% & - & - & - \\
\hline & & & & A $55 \%$ & - & - & - & - & - & A $68 \%$ & - & - & - \\
\hline & IC-37 & 7 & $\mathrm{~N}$ & - & G $57 \%$ & - & - & - & - & - & G $11 \%$ & - & - \\
\hline & & & & - & A $43 \%$ & - & - & - & - & - & A $89 \%$ & - & - \\
\hline & IC-58 & 8 & $\mathrm{~N}$ & - & - & - & - & - & - & G 31\% & - & - & - \\
\hline & & & & - & - & - & - & - & - & A $69 \%$ & - & - & - \\
\hline & IC-62 & 12 & $\mathrm{~N}$ & G 38\% & - & - & - & - & - & G $41 \%$ & - & G $100 \%$ & - \\
\hline & & & & A $62 \%$ & - & - & - & - & - & A $59 \%$ & - & А $0 \% \dagger$ & - \\
\hline & IC-46 & 10 & A & $\mathrm{Bi}$ & - & - & - & - & - & $\mathrm{Bi}$ & - & - & - \\
\hline & IC-57 & 7.5 & $\mathrm{~N}$ & $\mathrm{Bi}$ & $\mathrm{Bi}$ & - & - & - & - & - & - & - & - \\
\hline & IC-77 & 14 & G & - & $\underline{B i}$ & - & - & - & - & $\underline{\mathbf{G}}>\mathbf{A}$ & - & $\underline{\mathbf{G}}$ & - \\
\hline \multirow[t]{9}{*}{ ॥ } & UA-D & - & - & G 47\% & - & - & - & - & - & - & G 61\% & - & - \\
\hline & & & & A $53 \%$ & - & - & - & - & - & - & A $39 \%$ & - & - \\
\hline & IC-37 & 7 & G & G 55\% & G 60\% & - & G 65\% & - & - & G $100 \%$ & G $82 \%$ & - & - \\
\hline & & & & A $45 \%$ & A $40 \%$ & - & A $35 \%$ & - & - & A 0\%† & A $18 \%$ & - & - \\
\hline & IC-56 & 11 & $A$ & $\mathrm{Bi}$ & - & - & - & G $40 \%$ & G 39\% & G 37\% & - & - & G $26 \%$ \\
\hline & & & & - & - & - & - & A $60 \%$ & A $61 \%$ & A $63 \%$ & - & - & A $74 \%$ \\
\hline & IC-46 & 10 & $G$ & $\mathrm{Bi}$ & - & - & - & $\mathrm{Bi}$ & - & - & - & - & - \\
\hline & IC-58 & 8 & A & - & - & - & - & - & $\mathrm{Bi}$ & - & - & - & - \\
\hline & IC-77 & 14 & $\mathrm{~N}$ & - & $\underline{B i}$ & $\mathrm{Bi}$ & $\mathrm{Bi}$ & - & $\mathrm{Bi}$ & $\underline{B i}$ & - & $\underline{\mathbf{G}}$ & $\mathrm{Bi}$ \\
\hline
\end{tabular}

*Gestation week; †The peak in SNaPshot assay was too small to measure.

For mother's genotype, $\mathrm{N}$ indicates heterozygous, and $\mathrm{G}$ or $\mathrm{A}$ indicates homozygous for the SNP site used. Bi, $\mathrm{G}>\mathrm{A}$, and $\mathrm{C}$ or $\mathrm{G}$ indicate biallelic expression, preferential expression, and monoallelic expression, respectively (the samples showing preferential and monoallelic expression are highlighted in bold). The samples in which the expression ratio of one allele is greater than $70 \%$ are highlighted in bold. Sequencing electropherograms for the underlined sample are shown in fig $3 \mathrm{~A}$. 


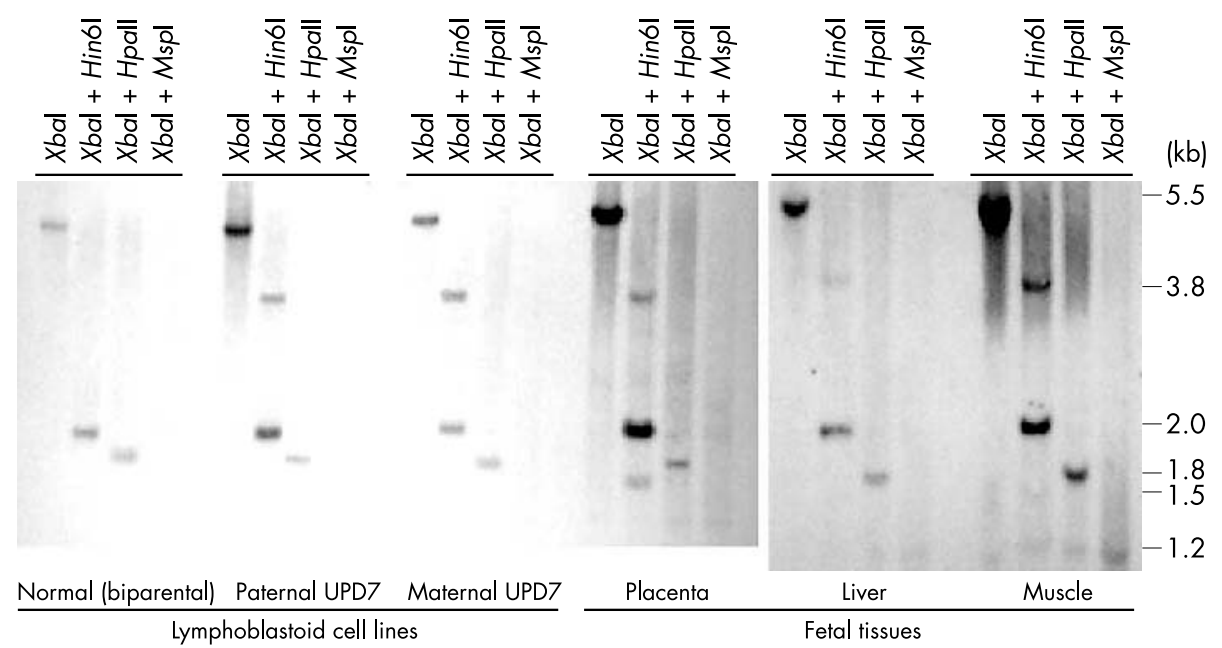

Figure 4 DNA methylation analysis for the $\mathrm{CpG}$ island located at the $5^{\prime}$ end of the human PPPIR9A gene by Southern blot hybridisation. A $1.3 \mathrm{~kb}$ probe encompassing a CpG island overlapping with exon 1 of PPPIR9A was hybridised with blots containing genomic DNA digested with Xbal only, Xbal and Hinbl, Xbal and Hpall, and Xbal and Mspl. Genomic DNA samples used were prepared from three lymphoblastoid cell lines (normal, paternal UPD7, and maternal UPD7) and three fetal tissues (placenta, liver, and muscle). The approximate band sizes are shown on the right.

other tissues or other developmental stages that were not analysed in this study.

The extent of preferential maternal expression of Ppplr9a was found to be strain-dependent in mouse. Imprinting was more relaxed when the paternal allele was derived from C57BL/6J (B) than from CAST/Ei (C) or JFl/Ms $(\mathrm{J})$ in all tissues and stages where preferential maternal expression was detected. Variations in the extent of preferential expression were also observed in humans (table 1). Therefore, in both humans and mice, differences in genetic background seem to affect the imprinting regulation of
PPPIR9A (polymorphic imprinting). Strain-dependent relaxation of imprinting has been reported in the mouse Kvlqtl gene in reciprocal crosses between 129/Sv and CAST/Ei. ${ }^{11}$

Although the number of genes identified to demonstrate tissue specific imprinting is increasing, ${ }^{4-9}$ the molecular mechanisms underlying this phenomenon are largely uncharacterised. Our DNA methylation analysis for the $\mathrm{CpG}$ island overlapping with exon 1 of PPPIR9A in human lymphoblastoid cell lines and fetal tissues did not reveal any evidence of differential methylation in a parent-of-origin or a tissue specific manner. The methylation status of the
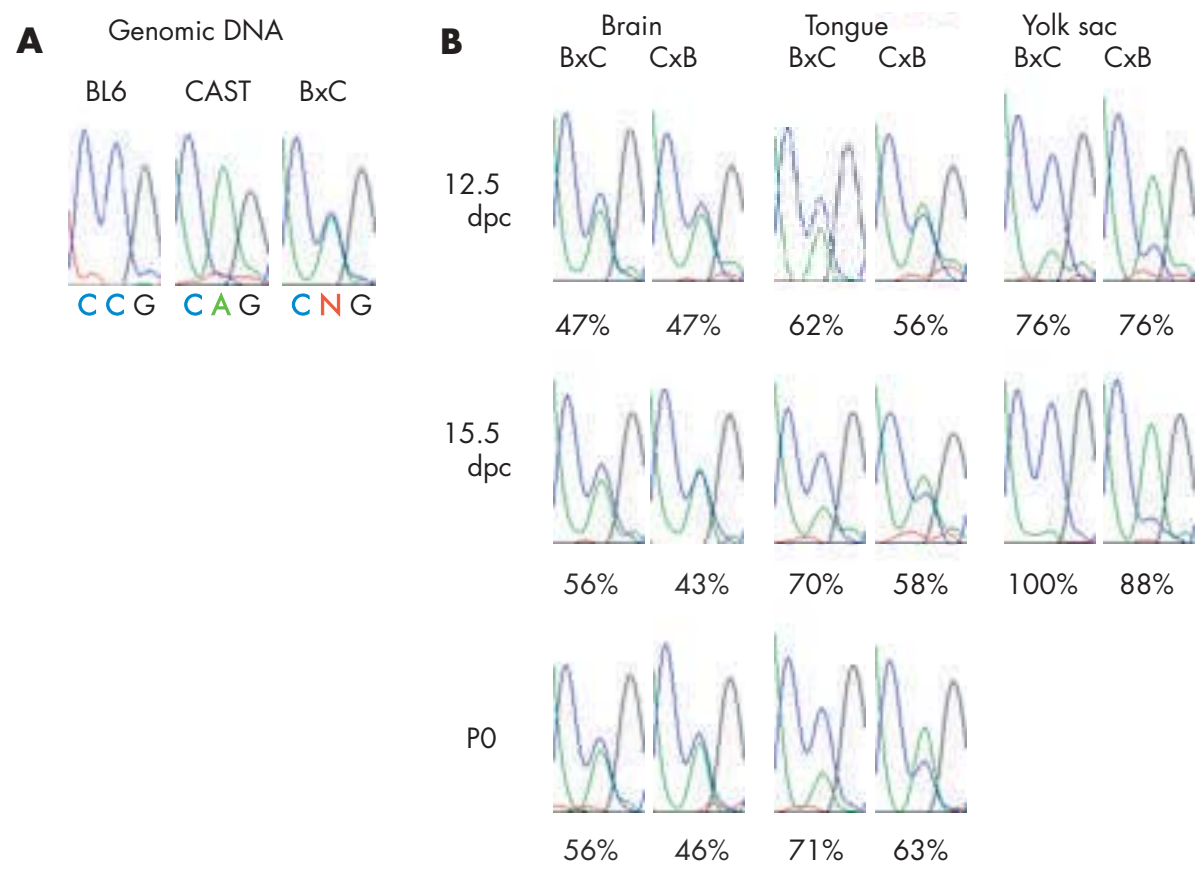

Figure 5 Allelic expression analysis for the mouse Ppp 1 r9a gene. (A) Electropherograms for sequencing of genomic DNA for an SNP in exon 2 of Ppplr9 are shown. Nt 616 of GenBank acc. number AY308065 for mouse Ppp1r9a mRNA was found to be polymorphic between B6 and CAST strains. B6 and CAST were homozygous for $C$ allele and A allele, respectively. As a result, BxC and CxB hybrids were heterozygous for the SNP site (only the result from BxC hybrid is shown). (B) Electropherograms for sequencing of RT-PCR products (for brain, tongue, and yolk sac) are shown. Embryonic tissues from three developmental stages (12.5 dpc, $15.5 \mathrm{dpc}$, and postnatal (PO)) were analysed. The expression ratio of maternal allele (C allele in $\mathrm{BxC}$ and $\mathrm{A}$ allele in $\mathrm{CxB}$ ) determined by SNaPshot assay is shown for each sample. 


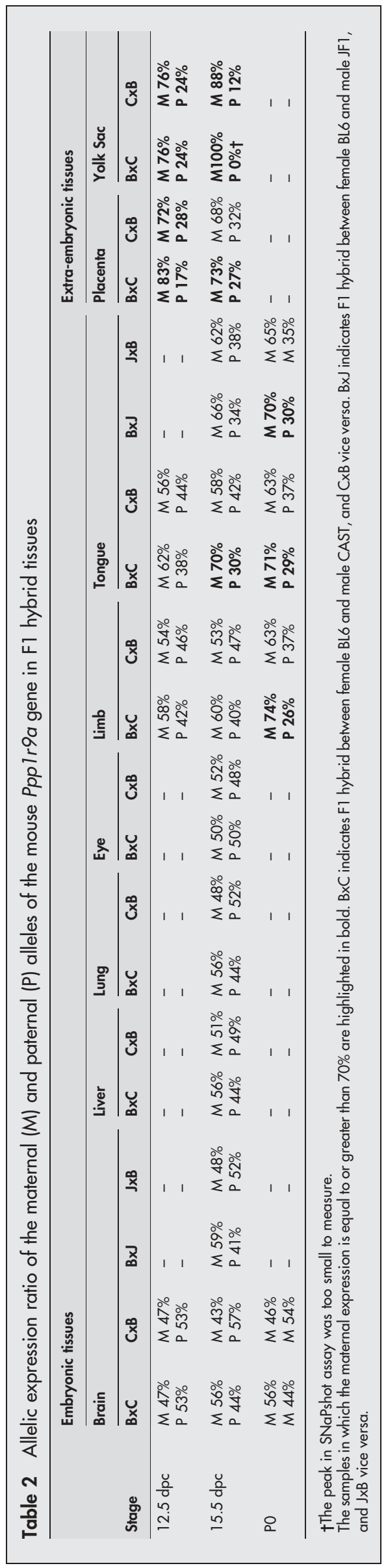

CpG island at the 5' end of the mouse PppIr9a was examined in mouse $10 \mathrm{dpc}$ embryo and placenta, and the CpG island was also not found to be methylated. ${ }^{20}$ These results indicate that the tissue specific maternal expression of the human and mouse PPPIR9A gene is not regulated by the methylation status of the CpG island at exon 1.

Yamasaki et $a l^{7}$ demonstrated cell type specific imprinting of the Ube3a gene. Ube $3 a$ is expressed maternally in neurons, but biallelically in glial cells, whereas the antisense transcript overlapping with Ube3a was expressed only in neurons and only from the paternal allele. Reciprocal imprinting of sense and antisense transcripts present only in neurons suggests that the neuron specific imprinting mechanism is related to the lineage determination of neural stem cells. ${ }^{7}$ Similar to the developmental regulation of imprinting of Ubeza in the neuronal lineage, the preferential maternal expression of PppIr9a in skeletal muscle tissue was found to become more prevalent at later developmental stages. This suggests that the imprinting mechanism for Ppplr9a in skeletal muscle tissues may be related to the commitment of myoblast differentiation.

In skeletal muscle differentiation, the fusion of mononucleated myoblasts to form multi-nucleated myotubes is a prominent event requiring reorganisation of actin cytoskeleton. ${ }^{37}$ Furthermore, PPl activity has been shown to be required for the fusion of embryonic muscle cells. ${ }^{38}$ Considering that neurabin I is an inhibitory subunit for PPl and an F-actin binding protein, the protein may have a key role in skeletal muscle differentiation. As such, changes in dosage of neurabin I may impair proper development of skeletal muscle.

Chimeras between normal and uniparental mouse embryos have provided an ideal system to investigate the results of genomic imprinting during prenatal and postnatal development. ${ }^{39-41}$ This is due to the fact that the selective elimination of uniparental cells has been observed in a spatial and/or temporal specific manner when imprinted genes have critical functions in embryonic development. Interestingly, skeletal muscle specific imprinting was predicted to exist based on studies using the chimeric normal/parthenogenetic embryo system $^{42-44}$; selection against the parthenogenetic cells was observed in a tissue specific manner, most strikingly in tongue, ${ }^{44}$ indicating the need for tissue specific imprinted differentiation gene(s) in tongue development. The selective elimination of parthenogenetic cells from the tongue of chimeric embryos was found to occur between days 13 and 15 of development, coinciding with the beginning of myoblast fusion. ${ }^{44}$ Taking into consideration the known features of the neurabin I protein and the expression/imprinting patterns of Ppplr9a shown in our study, neurabin I is a candidate molecule to be causal for the selective elimination of parthenogenetic cells from the tongue of chimeric embryos.

\section{ACKNOWLEDGEMENTS}

We acknowledge the technical assistance of The Centre for Applied Genomics (http://tcag.bioinfo.sickkids.on.ca/) at The Hospital for Sick Children. KN is a fellow of CIHR. SWS is an Investigator of CIHR and International Scholar of the Howard Hughes Medical Institute.

\footnotetext{
Authors' affiliations

K Nakabayashi, S Minagawa, A C Smith, L Parker-Katiraee, T Paton,

S W Scherer, Genetics and Genomic Biology Program, The Hospital for Sick Children, and Department of Molecular and Medical Genetics, University of Toronto, Toronto, ON, Canada M5G 1X8

S Makino, P Mill, Y Yoshikawa, C C Hui, Developmental Biology Program, The Hospital for Sick Children, and Department of Molecular and Medical Genetics, University of Toronto, Toronto, ON, Canada M5G 1 X8

J S Bamforth, Department of Medical Genetics, University of Alberta, Edmonton, AB, Canada T6G 2H7

P Stanier, D Monk, G E Moore, Institute of Reproductive and Developmental Biology, Imperial College, London, W12 ONN, UK
} 
M Preece, Institute of Child Health, London, WCIN 1EH, UK M Oshimura, Faculty of Medicine, Tottori University, Yonago, 6838503, Japan

This research is supported by grants from the Canadian Institutes of Health Research (CIHR) and Genome Canada.

Conflict of interest: none declared.

*These two authors contributed equally to this manuscript.

tCurrent address: Kihara Institute for Biological Research, Graduate School of Integrated Science, Yokohama City University, Yokohama, 244-0813, Japan

¥Current address: Faculty of Medicine, Yamaguchi University, Yamaguchi, 753-851 1, Japan.

Data deposition: GenBank accession number, AY308065.

Correspondence to: Dr S W Scherer, Genetics and Genomic Biology Program, Rm 9107, The Hospital for Sick Children, Toronto, ON, Canada M5G 1X8; steve@genet.sickkids.on.ca

Received 17 February 2004

Accepted for publication 20 February 2004

\section{REFERENCES}

1 Tilghman SM. The sins of the fathers and mothers: genomic imprinting in mammalian development. Cell 1999;96:185-93.

2 Reik W, Walter J. Genomic imprinting: parental influence on the genome. Nat Rev Genet 2001;2:21-32.

3 Morison IM, Reeve AE. A catalogue of imprinted genes and parent-of-origin effects in humans and animals. Hum Mol Genet 1998;7:1599-609.

4 Weinstein LS. The role of tissue-specific imprinting as a source of phenotypic heterogeneity in human disease. Biol Psychiatry 2001;50:927-31.

5 Blagitko N, Mergenthaler S, Schultz U, Wollmann HA, Craigen W, Eggermann T, Ropers HH, Kalscheuer VM. Human GRB10 is imprinted and expressed from the paternal and maternal allele in a highly tissue- and isoform-specific fashion. Hum Mol Genet 2000;9:1587-95.

6 Mizuno $Y$, Sotomaru $Y$, Katsuzawa $Y$, Kono $T$, Meguro M, Oshimura $M$, Kawai J, Tomaru Y, Kiyosawa H, Nikaido I, Amanuma H, Hayashizaki Y, Okazaki Y. Asb4, Ata3, and Dcn are novel imprinted genes identified by high-throughput screening using RIKEN cDNA microarray. Biochem Biophys Res Commun 2002;290:1499-505.

7 Yamasaki K, Joh K, Ohta T, Masuzaki H, Ishimaru T, Mukai T, Niikawa N, Ogawa M, Wagstaff J, Kishino T. Neurons but not glial cells show reciprocal imprinting of sense and antisense transcripts of Ube3a. Hum Mol Genet 2003; 12:837-47

8 Sandell LL, Guan XJ, Ingram R, Tilghman SM. Gatm, a creatine synthesis enzyme is imprinted in mouse placenta. Proc Natl Acad Sci U S A 2003;100:4622-27.

9 Hoshiya H, Meguro M, Kashiwagi A, Okita C, Oshimura M. Calcr, a brainspecific imprinted mouse calcitonin receptor gene in the imprinted cluster of the proximal. region of chromosome 6. J Hum Genet 2003;48:208-11

10 Gould TD, Pfeifer K. Imprinting of mouse Kvlqtl is developmentally regulated. Hum Mol Genet 1998;7:483-7.

11 Jiang S, Hemann MA, Lee MP, Feinberg AP. Strain-dependent developmental relaxation of imprinting of an endogenous mouse gene, Kvlqt1. Genomics 1998:53:395-9.

12 Bunzel R, Blumcke I, Cichon S, Normann S, Schramm J, Propping P, Nothen MM. Polymorphic imprinting of the serotonin-2A (5-HT2A) receptor gene in human adult brain. Brain Res Mol Brain Res 1998;59:90-2.

13 Sakatani T, Wei M, Katoh M, Okita C, Wada D, Mitsuya K, Meguro M, Ikeguchi $M$, Ito $H$, Tycko $B$, Oshimura $M$. Epigenetic heterogeneity at imprinted loci in normal populations. Biochem Biophys Res Commun 2001;283:1124-30.

14 Scherer SW, Cheung J, MacDonald JR, Osborne LR, Nakabayashi K, Herbrick JA, Carson AR, Parker-Katiraee L, Skaug J, Khaja R, Zhang J Hudek AK, Li M, Haddad M, Duggan GE, Fernandez BA, Kanematsu $E$ Gentles S, Christopoulos CC, Choufani S, Kwasnicka D, Zheng XH, Lai Z, Nusskern D, Zhang Q, Gu Z, Lu F, Zeesman S, Nowaczyk MJ, Teshima I, Chitayat D, Shuman C, Weksberg R, Zackai EH, Grebe TA, Cox SR, Kirkpatrick SJ, Rahman N, Friedman JM, Heng HH, Pelicci PG, Lo-Coco F, Belloni E, Shaffer LG, Pober B, Morton CC, Gusella JF, Bruns GA, Korf BR, Quade BJ, Ligon AH, Ferguson $H$, Higgins AW, Leach NT, Herrick SR, Lemyre E, Farra CG, Kim HG, Summers AM, Gripp KW, Roberts W, Szatmari P, Winsor EJ, Grzeschik KH, Teebi A, Minassian BA, Kere'J, Armengol L, Pujana MA, Estivill X, Wilson MD, Koop BF, Tosi S, Moore GE Boright AP, Zlotorynski E, Kerem B, Kroisel PM, Petek E, Oscier DG, Mould SJ Dohner H, Dohner K, Rommens JM, Vincent JB, Venter JC, Li PW, Mural RJ Adams MD, Tsui LC. Human chromosome 7: DNA sequence and biology. Science 2003;300:767-72

15 Piras G, El-Kharroubi A, Kozlov S, Escalante-Alcalde D, Hernandez L, Copeland NG, Gilbert DJ, Jenkins NA, Stewart CL. Zacl (Lot7), a potential tumor suppressor gene, and the gene for epsilon-sarcoglycan are maternally imprinted genes: identification by a subtractive screen of novel uniparental fibroblast lines. Mol Cell Biol 2000;20:3308-15

16 Zimprich A, Grabowski M, Asmus F, Naumann M, Berg D, Bertram M, Scheidtmann K, Kern P, Winkelmann J, Muller-Myhsok B, Riedel L, Baver M, Muller T, Castro M, Meitinger T, Strom T-M, Gasser T. Mutations in the gene encoding epsilon-sarcoglycan cause myoclonus-dystonia syndrome. Nat Genet 2001;29:66-9.

17 Grabowski M, Zimprich A, Lorenz-Depiereux B, Kalscheuer V, Asmus F, Gasser T, Meitinger T, Strom TM. The epsilon-sarcoglycan gene (SGCE), mutated in myoclonus-dystonia syndrome, is maternally imprinted. Eur J Hum Genet 2003;11:138-44.

18 Muller B, Hedrich K, Kock N, Dragasevic N, Svetel M, Garrels J, Landt O, Nitschke M, Pramstaller PP, Reik W, Schwinger E, Sperner J, Ozelius L Kostic V, Klein C. Evidence that paternal expression of the epsilon-sarcoglycan gene accounts for reduced penetrance in myoclonus-dystonia. Am J Hum Genet 2002;71:1303-11.

19 Ono R, Kobayashi S, Wagatsuma H, Aisaka K, Kohda T, Kaneko-Ishino T, Ishino $F$. A retrotransposon-derived gene, PEG10, is a novel imprinted gene located on human chromosome 7q21. Genomics 2001;73:232-7.

20 Ono R, Shiura H, Aburatani A, Kohda T, Kaneko-Ishino T, Ishino F. Identification of a large novel imprinted gene cluster on mouse proximal chromosome 6. Genome Res 2003;13:1696-705.

21 Okita C, Meguro M, Hoshiya H, Haruta M, Sakamoto Y, Oshimura M. A new imprinted cluster on the human chromosome 7q21-q31 identified by humanmouse monochromosomal hybrids. Genomics 2003;81:556-9.

22 Nakanishi H, Obaishi H, Satoh A, Wada M, Mandai K, Satoh K, Nishioka H, Matsuura Y, Mizoguchi A, Takai Y. Neurabin: a novel neural tissue-specific actin filament-binding protein involved in neurite formation. J Cell Biol 1997; 139:951-61

23 Burnett PE, Blackshaw S, Lai MM, Qureshi IA, Burnett AF, Sabatini DM, Snyder SH. Neurabin is a synaptic protein linking p70 S6 kinase and the neuronal cytoskeleton. Proc Natl Acad Sci U S A 1998:95:8351-6.

24 McAvoy T, Allen PB, Obaishi H, Nakanishi H, Takai Y, Greengard P, Nairn AC, Hemmings HC Jr. Regulation of neurabin I interaction with protein phosphatase 1 by phosphorylation. Biochemistry 1999;38:12943-9.

25 Oliver CJ, Terry-Lorenzo RT, Elliott E, Bloomer WA, Li S, Brautigan DL, Colbran RJ, Shenolikar S. Targeting protein phosphatase 1 (PP1) to the actin cytoskeleton: the neurabin I/PP1 complex regulates cell morphology. Mol Cell Biol 2002;22:4690-701

26 Penzes $P$, Johnson RC, Sattler R, Zhang X, Huganir RL, Kambampati V, Mains RE, Eipper BA. The neuronal Rho-GEF Kalirin-7 interacts with PDZ domain-containing proteins and regulates dendritic morphogenesis. Neuron $2001 ; 29: 229-42$

27 Stephens DJ, Banting G. Direct interaction of the trans-Golgi network membrane protein TGN38 with the F-actin binding protein neurabin. J Biol Chem 1999;274:30080-6.

28 Davies W, Isles AR, Wilkinson LS. Imprinted genes and mental dysfunction. Ann Med $2001 ; 33: 428-36$.

29 Keverne EB. Genomic imprinting and the maternal brain. Prog Brain Res $2001 ; 133: 279-85$

30 Nakabayashi K, Fernandez BA, Teshima I, Shuman C, Proud VK, Curry CJ, Chitayat D, Grebe T, Ming J, Oshimura M, Meguro M, Mitsuya K, Deb-Rinker P, Herbrick JA, Weksberg R, Scherer SW. Molecular genetic studies of human chromosome 7 in Russell-Silver syndrome. Genomics 2002;79:186-96.

31 Hui CC, Joyner AL. A mouse model of greig cephalopolysyndactyly syndrome: the extra-toesJ mutation contains an intragenic deletion of the Gli3 gene. Nat Genet 1993;3:241-6

32 Norton N, Williams NM, Williams HJ, Spurlock G, Kirov G, Morris DW, Hoogendoor B, Owen MJ, O'Donovan MC. Universal, robust, highly quantitative SNP allele frequency measurement in DNA pools. Hum Genet 2002;1 10:471-8.

33 Preece MA, Abu-Amero SN, Ali Z, Abu-Amero KK, Wakeling EL, Stanier P Moore GE. An analysis of the distribution of hetero- and isodisomic regions of chromosome 7 in five mUPD7 Silver-Russell syndrome probands. J Med Genet 1999;36:457-60

34 Duhadaway J, Rowe F, Elliott K, Mao NC, Prendergast GC. Bau, a splice form of Neurabin-I that interacts with the tumor suppressor Bin 1, inhibits malignant cell transformation. Cell Adhes Commun 1999;7:99-110.

35 Hoogendoorn B, Norton N, Kirov G, Williams N, Hamshere ML, Spurlock G, Austin J, Stephens MK, Buckland PR, Owen MJ, O'Donovan MC. Cheap, accurate and rapid allele frequency estimation of single nucleotide polymorphisms by primer extension and DHPLC in DNA pools. Hum Genet 2000;107:488-93.

36 Uhlmann K, Brinckmann A, Toliat MR, Ritter H, Nurnberg P. Evaluation of a potential epigenetic biomarker by quantitative methyl-single nucleotide polymorphism analysis. Electrophoresis 2002;23:4072-9.

37 Shuler CF, Dalrymple KR. Molecular regulation of tongue and craniofacial muscle differentiation. Crit Rev Oral Biol Med 2001;12:3-17.

$38 \mathrm{Kim}$ SS, Kim JH, Lee SH, Chung SS, Bang OS, Park D, Chung CH. Involvement of protein phosphatase-1-mediated MARCKS translocation in myogenic differentiation of embryonic muscle cells. J Cell Sci 2002;115:2465-73.

39 Solter D. Differential imprinting and expression of maternal and paternal genomes. Annu Rev Genet 1988;22:127-46.

40 Ferguson-Smith AC, Cattanach BM, Barton SC, Beechey CV, Surani MA. Embryological and molecular investigations of parental imprinting on mouse chromosome 7. Nature 1991;351:667-70.

41 Jagerbauer EM, Fraser A, Herbst EW, Kothary R, Fundele R. Parthenogenetic stem cells in postnatal mouse chimeras. Development 1992;116:95-102.

42 Fundele R, Norris ML, Barton SC, Reik W, Surani MA. Systematic elimination of parthenogenetic cells in mouse chimeras. Development 1989;106:29-35.

43 Nagy A, Sass M, Markkula M. Systematic non-uniform distribution of parthenogenetic cells in adult mouse chimaeras. Development 1989;106:321-4.

44 Fundele RH, Norris ML, Barton SC, Fehlau M, Howlett SK, Mills WE, Surani MA. Temporal and spatial selection against parthenogenetic cells during development of fetal chimeras. Development 1990;108:203-11. 